\title{
Influence of canine brain decomposition on laboratory diagnosis of rabies
}

\author{
Influência da decomposição do cérebro de cães no diagnóstico \\ laboratorial da raiva
}

\author{
Avelino Albas, Clara Izabel de Lucca Ferrari, Luzia Helena Queiroz da Silva, \\ Fernanda Bernardi and Fumio Honma Ito
}

\begin{abstract}
Canine brains infected with rabies virus were submitted to decomposition by being left at room temperature of 25 to $29^{\circ} \mathrm{C}$ for up to $168 \mathrm{~h}$. At $24 \mathrm{~h}$ intervals, brain fragments were analyzed by immunofluorescence (IF) and by the mouse intracerebral inoculation (MI) test to confirm the diagnosis of rabies and to measure the putrefaction effect on the accuracy of the diagnosis. Forty eight $h$ after the beginning of the experiment, the MI test showed signs of impairment with four negative results, while after $72 \mathrm{~h}, 100 \%$ of the results were negative to the MI test and only one result was negative to the IF test, indicating that the threshold period for accurate diagnosis is 24 to $48 \mathrm{~h}$ before putrefaction. The authors recommend the shipment of suspected cases of rabies to the laboratory for confirmation, but the use of putrid materials for diagnosis is meaningless because of false-negative results.
\end{abstract}

Key-words: Immunofluorescence. Rabies. Mice inoculation. Decomposition. Canine brain.

Resumo Cérebros de cães infectados com o vírus da raiva foram submetidos à decomposição, deixando-os à temperatura ambiente de 25 a $29^{\circ} \mathrm{C}$ por até 168 horas. A cada 24 horas, fragmentos de cérebros foram analisados pela imunofluorescência (IF) e inoculação intracerebral em camundongos (IC) para confirmar o diagnóstico de raiva e medir o efeito da putrefação na acurácia do teste. Após 48 horas do início do experimento o teste de IC começou a ser prejudicado, detectando-se quatro resultados negativos, enquanto que, após 72 horas, $100 \%$ dos resultados foram negativos para IC e apenas um foi negativo para IF, indicando que o período limite para um diagnóstico seguro está entre 24 e 48 horas antes da putrefação. Os autores recomendam o envio de material suspeito para o diagnóstico laboratorial, no entanto, o uso de materiais em adiantado estado de decomposição não é adequado, devido à ocorrência de resultados falsos-negativos.

Palavras-chaves: Imunofluorescência. Raiva. Inoculação em camundongos. Decomposição, cérebro de cão.

According to information of Boletín de Vigilancia Epidemiologica de la Rabia en las Americas ${ }^{4}$, Brazil is indicated with the highest cases of human rabies in Latin American countries; although reports of bats provoking human rabies have been increasing nowadays, but dogs are still the main reservoirs. Isolations of rabies virus from non-hematophagous bats

Núcleo Regional de Presidente Prudente do Instituto Biológico; Laboratório de Sanidade Animal e Vegetal de Araçatuba; Departamento de Medicina Veterinária da Universidade Estadual Paulista, Araçatuba, SP; Departamento de Medicina Veterinária Preventiva e Saúde Animal da Faculdade de Medicina Veterinária e Zootecnia da Universidade de São Paulo, São Paulo, SP.

Address to: Avelino Albas. Núcleo Regional de Presidente Prudente/Instituto Biológico. Caixa Postal 298, 19001-970 Presidente Prudente, SP, Brasil.

Telefax: 5518 222-8688

Recebido para publicação em 14/7/97. 
have been increasingly common in several regions of the world2 79 , probably these viruses belong to genotype 5 or 6 of EBL 1 or EBL 22 .

The livestock industry in these regions is severely affected by rabies, causing heavy economic losses due to high mortality rates especially in bovines 18 .

The laboratory diagnosis of rabies is essential for the guiding of control programs, and for the establishment of epidemiological surveillance and for the effective monitoring of one geographical area, as well as for orientation of prophylactic measures. Among the methods recommended by WHO experts on rabies ${ }^{14}$, the immunofluorescent (IF) technique accompanied by mouse intracerebral inoculation (MI) test are the best choices for this purpose, because results could be used wether to continue or not the rabies treatment, with or without indication of rabies anti-serum, as specified in the Manual

fail.

\section{MATERIAL AND METHODS}

Brains. Among the brain materials shipped for routine laboratory diagnosis of rabies, ten positive canine brains were selected for this study. The direct IF technique was according to Dean et al3, using for each specimen, two microscopic glass slides for making smears by the impression method and for already decomposed brains, thin film smears were prepared.

Anti-nucleocapside rabies polyclonal conjugate used was from SANOFI Diagnostics, Pasteur/France, and the microscope used was the Carl Zeiss, Janalumar model.

The MI technique was according to Koprowski5, using a $20 \%$ brain suspension by weight, and the diluent was prepared by using sterile distilled water added to $2 \%$ normal horse serum, with $500 \mathrm{IU}$ of penicillin and $500 \mu \mathrm{g}$ of streptomycin per $\mathrm{ml}$ and centrifuged at $1500 \mathrm{rpm}$ for ten minutes.

After $48 \mathrm{~h}$ of storage at room temperature of $25-29^{\circ} \mathrm{C}, 10 \%$ brain suspensions were obtained from tissues already in decomposition and the suspensions were kept in ice bath soon after centrifugation. Each brain suspension was
Atualizado de Normas Técnicas de Profilaxia da Raiva em Humanos6.

The results of laboratory diagnosis must be accurate and safe, one factor that impairs rabies diagnosis could be the state of conservation of brain tissues. Fluorescent antigen may be seen in putrid rabies specimens, but one cannot predict at which time the diagnostic method begins to fail13. The use of decomposed specimens could imply in false positive or false negative results. In many rabies diagnostic centers the reception of decomposed brain specimens are still very frequent (FH Ito: personal communication, 1997), and due to important question concerning accurate confirmation of rabies, the present paper has been designed to experimentally assesses the influence of the state of conservation of brain specimens submitted to rabies diagnosis and to determine the time the diagnostic method of IF and MI tests begin to

inoculated in each group of 8 mice weighing 11 to $14 \mathrm{~g}$, through intracerebral route, and observed for 21 days and searched for rabies signs and symptoms, and mice found in agonizing state or dead were again submitted to IF test for rabies confirmation.

Procedures. The brains selected had been previously confirmed as rabid, by means of IF and $\mathrm{MI}$ techniques and stored frozen until the beginning of the experiment. The criteria for determination of IF positivity were based on fluorescence, and brightness of inclusion bodies and presence of sandlike particles and registered as + to +++++. The + degree was registered for a positive material showing very few inclusion bodies with weak brightness and absence of sandlike particles. The +++++ was used for materials showing numerous round and oval shaped inclusion bodies with typical brightness. The other degrees were used to indicate intermediate results. For evaluation, each brain was simultaneously defrosted and kept in Petri dish at room temperature varying from 25 to $29^{\circ} \mathrm{C}$ for up to $168 \mathrm{~h}$ in order to provoke tissue decomposition. Searching for the presence of rabies antigens and the isolation of virus were made by means of MI and IF tests, at each $24 \mathrm{~h}$ interval.

RESULTS

The results of IF test are summarized in
Table 1; the fluorescent brightness has decreased as the time of exposure at 25 to $29^{\circ} \mathrm{C}$ has evolved. After $72 \mathrm{~h}$ of exposition, $90 \%$ of materials 
have been found positive, however after $96 \mathrm{~h}$ from the beginning of the experiment two samples were found negative, and after $120 \mathrm{~h}$, only two out of ten materials examined were positive, and after $144 \mathrm{~h}$, only one specimen was positive. After 7 days (168h), none of the materials were found to have any fluorescent particles.
In relation to $\mathrm{MI}$ test (Table 1 ), mice inoculated with suspension made of brain left at room temperature for $24 \mathrm{~h}$ showed symptoms and signs of rabies in $100 \%$ of mice examined. After $48 \mathrm{~h}$ of temperature treatment, six specimens still were found positive through MI test. However, $100 \%$ of inoculated mice were negative with materials

Table 1 - Canine brains submitted at each 24 hour interval to direct immunofluorescence (IF) and mouse inoculation (MI) test after being stored at room temperature of 25 to $29^{\circ} \mathrm{C}$, for period of up to $168 \mathrm{~h}$.

\begin{tabular}{|c|c|c|c|c|c|c|c|c|c|c|c|c|c|c|c|c|}
\hline \multirow[t]{2}{*}{ Time (h)/ Sample } & \multicolumn{2}{|c|}{0} & \multicolumn{2}{|c|}{24} & \multicolumn{2}{|c|}{48} & \multicolumn{2}{|c|}{72} & \multicolumn{2}{|c|}{96} & \multicolumn{2}{|c|}{120} & \multicolumn{2}{|c|}{144} & \multicolumn{2}{|c|}{168} \\
\hline & $\mathrm{IF}^{*}$ & MI & IF & $\mathrm{MI}$ & IF & $\mathrm{MI}$ & IF & $\mathrm{MI}$ & IF & $\mathrm{MI}$ & IF & $\mathrm{MI}$ & IF & $\mathrm{MI}$ & IF & $\mathrm{MI}$ \\
\hline 1 & ++ & $P$ & + & $P$ & + & $P$ & + & $\mathrm{N}$ & + & $\mathrm{N}$ & $\mathrm{N}$ & $\mathrm{N}$ & $\mathrm{N}$ & $\mathrm{N}$ & $\mathrm{N}$ & $\mathrm{N}$ \\
\hline 2 & +++ & $\mathrm{P}$ & +++ & $\mathrm{P}$ & ++ & $\mathrm{N}$ & + & $\mathrm{N}$ & + & $\mathrm{N}$ & $\mathrm{N}$ & $\mathrm{N}$ & $\mathrm{N}$ & $N$ & $\mathrm{~N}$ & $\mathrm{~N}$ \\
\hline 3 & ++++ & $\mathrm{P}$ & ++ & $P$ & ++ & $\mathrm{P}$ & + & $\mathrm{N}$ & $\mathrm{N}$ & $\mathrm{N}$ & $\mathrm{N}$ & $\mathrm{N}$ & $\mathrm{N}$ & $N$ & $\mathrm{~N}$ & $\mathrm{~N}$ \\
\hline 4 & + & $\mathrm{P}$ & + & $P$ & + & $\mathrm{P}$ & + & $\mathrm{N}$ & + & $\mathrm{N}$ & $\mathrm{N}$ & $\mathrm{N}$ & $\mathrm{N}$ & $\mathrm{N}$ & $\mathrm{N}$ & $\mathrm{N}$ \\
\hline 5 & +++ & $\mathrm{P}$ & ++ & $\mathrm{P}$ & ++ & $P$ & ++ & $\mathrm{N}$ & ++ & $\mathrm{N}$ & $\mathrm{N}$ & $\mathrm{N}$ & $\mathrm{N}$ & $\mathrm{N}$ & $\mathrm{N}$ & $\mathrm{N}$ \\
\hline 6 & ++ & $\mathrm{P}$ & ++ & $\mathrm{P}$ & + & $P$ & $\mathrm{~N}$ & $\mathrm{~N}$ & $\mathrm{~N}$ & $\mathrm{~N}$ & $\mathrm{~N}$ & $\mathrm{~N}$ & $\mathrm{~N}$ & $\mathrm{~N}$ & $\mathrm{~N}$ & $\mathrm{~N}$ \\
\hline 7 & ++++ & $\mathrm{P}$ & ++++ & $\mathrm{P}$ & + & $\mathrm{N}$ & + & $\mathrm{N}$ & + & $\mathrm{N}$ & + & $\mathrm{N}$ & $\mathrm{N}$ & $N$ & $\mathrm{~N}$ & $\mathrm{~N}$ \\
\hline 8 & +++++ & $\mathrm{P}$ & +++++ & $\mathrm{P}$ & +++ & $P$ & +++ & $\mathrm{N}$ & ++ & $\mathrm{N}$ & + & $\mathrm{N}$ & + & $N$ & $\mathrm{~N}$ & $\mathrm{~N}$ \\
\hline 9 & +++ & $P$ & +++ & $P$ & ++ & $\mathrm{N}$ & + & $\mathrm{N}$ & + & $\mathrm{N}$ & $\mathrm{N}$ & $\mathrm{N}$ & $\mathrm{N}$ & $\mathrm{N}$ & $\mathrm{N}$ & $\mathrm{N}$ \\
\hline 10 & +++ & $P$ & ++ & $\mathrm{P}$ & ++ & $\mathrm{N}$ & + & $\mathrm{N}$ & + & $\mathrm{N}$ & $\mathrm{N}$ & $\mathrm{N}$ & $\mathrm{N}$ & $\mathrm{N}$ & $\mathrm{N}$ & $\mathrm{N}$ \\
\hline
\end{tabular}

${ }^{\star}$ Criteria adopted for evaluation of positivity, degree:,,,,$+++++++++++++++; \mathrm{P}=$ positive; $\mathrm{N}=$ negative.

stored for $72 \mathrm{~h}$, this result occurred in the following intervals until $168 \mathrm{~h}$.

\section{DISCUSSION}

The results found in this experiment corroborate to that reported by Winkler and Adams ${ }^{14}$ who stated that fluorescent antigen may still be seen in putrid rabies specimens after mouse inoculation, but one cannot predict the time the diagnostic method begins to fail. Valentini et al10 and Vasconcellos et al11, using mice brains, reported that the fluorescence of rabies antigens could still be identified in materials showing advanced stage of putrefaction. The findings of the specific fluorescence in these materials varied according to the state of decomposition. The impairment of Ml results could be felt after $48 \mathrm{~h}$ from the beginning of the experiment. Between 48 to $72 \mathrm{~h}$, the degree of putrefaction has increased, the brains became pasty, and for IF test, after this period, glasses were prepared through smears. In fact, the IF results, after $72 \mathrm{~h}$ showed only one negative brain while by means of $\mathrm{Ml}$ test, all materials examined were negative, increasing the discrepancy between the tests. After this period, both IF and MI test presented false negative results, being no more accurate.

Wachendorfer ${ }^{12}$, Valentini et al10 and
Vasconcellos et al11 also found higher frequency of disagreeing results between $\mathrm{Ml}$ and IF test in materials previously known to be rabid. In this respect, Valentini et al10 searching the presence of rabies antigens through IF test in mice inoculated with CVS strain of rabies virus and having been submitted to carcass decomposition at a temperature of $25^{\circ} \mathrm{C}$, for a period of $18 \mathrm{~h}$, still detected high positivity. In mice carcasses the putrefaction could be accelerated by postmortem migration of intestinal microorganisms to the whole carcass. In this experiment, however, we have used canine brains, greater than to that of mice and the materials had been stored separately from the carcasses, thus preventing the post-mortem migration and proliferation of intestinal microorganisms.

The putrefaction of brain tissues could alter the rabies diagnosis, increasing the discrepancies between the IF and MI results. The false negative results were first observed after $48 \mathrm{~h}$ through $\mathrm{MI}$ test. The authors encourage the shipment of specimens for diagnosing rabies, but the use of decomposed carcasses, especially when death has elapsed more than $48 \mathrm{~h}$ and in the absence of adequate means of conservation, the negative results are meaningless, particularly in cases of 


\section{disintering buried carcasses of suspected animals.}

\section{REFERENCES}

1. Acha PN, Malaga-Alba A. Economic losses due to Desmodus rotundus. In: Greenhall AM, Schmidt U (eds) Natural history of vampire bats. CRC Press, Boca Raton, p.207-214, 1988.

2. Brass DA. Rabies in bats. Natural history and public health implications. Livia Press, Ridgfield, Connecticut, 1994.

3. Dean DJ, Abelseth MK, Atanasiu P. The fluorescent antibody test. In: Meslin FX, Kaplan MM, Koprowski H. (eds) Laboratory techniques in rabies, World Health Organization, 4th edition. Ginebra, p. 75-87, 1996.

4. Instituto Panamericano de Protección de Alimentos y Zoonosis. Vigilancia epidemiologica de la rabia en las Americas. 1er semestre 1995. Publicação da Organização Mundial da Saúde, v.27, n.1/6, p.1-15, 1995.

5. Koprowiski H. The mouse inoculation test. In: Meslin FX, Kaplan MM, Koprowskih (eds) Laboratory techniques in rabies, World Health Organization, $4^{\mathrm{a}}$ ed. Ginebra, p. 80 87, 1996.

6. Manual de Normas Técnicas da Profilaxia da Raiva em Humanos. Secretaria de Saúde, $2^{\mathrm{a}}$ edição. São Paulo, 1996.

7. Martorelli LFA, Aguiar EAC, Almeida MF, Silva MMS, Novaes ECR. Isolamento do vírus rábico de morcego insetívoro Myotis nigricans, Revista de Saúde Pública 29:140-141, 1995.

8. Tadei VA, Gonçalves CA, Pedro WA, Tadei WJ, Kotait I,
Arieta C. Distribuição do morcego vampiro Desmodus rotundus (Chiroptera Phyllostomidae) no Estado de São Paulo e a raiva dos animais domésticos. Impresso Especial da Coordenadoria de Assistência Técnica Integral (CATI), Campinas, SP, 107 p, 1991.

9. Uieda W, Harmani NMS, Silva MMS. Raiva em morcegos insetívoros (molossidae) do Sudeste do Brasil. Revista de Saúde Pública 29:393-397, 1995.

10. Valentini EJG, Albas A, Mendes Augusto VL, Ito FH. Imunofluorescência realizada em cérebros de camundongos infectados com vírus rábico CVS em diferentes estágios de decomposição. Revista do Instituto de Medicina Tropical de São Paulo 3:181-186, 1991.

11. Vasconcellos MEP, Vasconcellos SA, Côrtes JA, Ito FH. Laboratory diagnosis of rabies by the fluorescent antibody test applied to brain tissues of experimentally inoculated mice and either preserved in formalin or under refrigeration. Brazilian Journal of Veterinary Research and Animal Science 30:21-24, 1993.

12. Wachendorfer Von G Fluoresceinmarkierte Antikorper in der Diagnostik vom Viruskrankheirter dargestellt an Modell der Tollwut. Deutsche Tieraztliche Wochenschrift 7:446-452, 1966.

13. Winkler WG, Adams DB, Kissling RE. The fluorescent antibody test in rabies. In: Baer GM (ed) The natural history of rabies, New York, Academic Press, v. 1, p. 401406, 1975.

14. World Health Organization Expert Committee on Rabies. 